\title{
Readability of Corporate Annual Reports of Top 100 Malaysian Companies
}

\author{
ROSLI MOHAMAD \\ AZHAR ABDUL RAHMAN \\ Faculty of Accountancy \\ Universiti Utara Malaysia
}

ABSTRACT

- The main purpose of this paper is to compare the readability of two narrative sections in Malaysian corporate annual reports. Further more the authors investigate whether readability of one section reflects the readability of another section. On top of that, consistency of the readability level across companies is also reviewed. The study assess the readability of the chairman's statement and notes to the accounts of top 100 Malaysian corporations using Flesch readability formula. Overall results indicated consistent finding with prior studies with which the readability of both narratives is considered as very difficult to read. Specifically, the findings revealed that the management does not present the chairman's statement in a more readable style despite greater flexibility offered in its presentation than notes to the accounts. Further test also confirmed that a readable chairman's statement is not necessarily followed by readable notes to the accounts and vice versa. Finally, the study reported that readability of notes to the accounts is more consistent among companies than the chairman's statement. It is therefore recommended that the management should consider presenting the chairman's statement in a plain English to ensure that investors accurately receive the conveyed message.

Keywords: Corporate Communication; Annual Reports; Chairman's statements; Flesch Readability Formula; Malaysian Companies.

\section{ABSTRAK}

Kajian ini membandingkan tahap kebolehbacaan dua laporan naratif yang terdapat di dalam laporan tahunan syarikat di Malaysia. Seterusnya, penulis cuba mengenal pasti sama ada kebolehbacaan satu bahagian laporan memberi kesan kepada tahap kebolehbacaan bahagian laporan yang lain. Di samping itu, ketekalan tahap kebolehbacaan di kalangan syarikat juga turut dinilai. Kajian ini menilai kebolehbacaan penyata pengerusi dan nota kepada akaun bagi 100 syarikat tersenarai di Malaysia menggunakan Formula kebolehbacaan Flesch. Hasil kajian mendapati tahap kebolehbacaan laporan pengerusi dan nota kepada akaun syarikat-syarikat tersebut adalah sangat sukar dibaca, selaras dengan penemuan kajian-kajian lepas. Khususnya, kajian mendapati bahawa pihak pengurusan tidak mempersembahkan laporan pengerusi dalam bahasa yang lebih mudah dibaca walaupun format persembahannya adalah lebih fleksibel berbanding nota kepada akaun. Selanjutnya, dapatan kajian tidak dapat membuktikan bahawa tahap kebolehbacaan laporan pengerusi sesebuah syarikat boleh mempengaruhi tahap kebolehbacaan nota kepada akaunnya. Akhir sekali, didapati tahap kebolehbacaan nota kepada akaun adalah lebih konsisten di antara syarikat berbanding laporan pengerusi. Adalah dicadangkan pihak pengurusan untuk mempersembahkan penyata pengerusi menggunakan bahasa Inggeris yang lebih mudah bagi memastikan pelabur menerima mesej yang dilaporkan dengan tepat. 


\section{INTRODUCTION}

The usefulness of annual reports to various stakeholders had been addressed in many studies (Jones, 1988a; Rezaee \& Porter, 1993; Chiu, 1996; Anderson, 1998). Specifically, Anderson (1998) and Jones (1988a) found that the majority of investors ranked the chairman's statement as the most widely read section of annual reports. Findings from prior studies also had indicated the increasing importance of the chairman's Statement to shareholders.

However, Chiu (1996) argued that the usefulness of annual reports is highly influenced by the audience background. For instance, trained investors and sophisticated users might perceive the usefulness of certain financial report section as they have sufficient knowledge to understand he reports. In contrast, unsophisticated or naïve investors with minimum knowledge of accounting or finance could find it difficult to understand the financial statements. Therefore, they would prefer to obtain information from other sections of the annual reports that are written in a less technical language.

- In view of the fact that non-financial namrative sections attract the attention of average, unsophisticated, or naïve investors, thus it is essential for corporate management to ensure it is used to communicate effectively the company's message. Effective communication is achieved when the readers correctly receive and interpret the message conveyed by the sender (Courtis, - 1995). However, a major obstacle normally results from the writing style that is difficult to read. Hence, readability becomes one of the most iohportant elements in achieving effective financial reporting communication.

The presentation of the non-financial narrative section is expected to be more readable than the financial narrative as it usually simplifies the information inherited from the financial statements (Courtis, 1987) while regulatory requirements on its presentation format are relatively minimal. Consequently, these would give the management wider flexibility, both in writing style and complexity of presentation (Schroeder \& Gibson, 1990).

Despite the belief that poor readability of non-financial narrative sections influences the level of reader understanding, to date there have been no studies indicating direct implication of having a less readable narrative in the annual report to company's financial performance. However, Subramaniam, Insley, and Blackwell (1993) highlighted that poor readability of those narratives might cause the company to miss its opportunity of getting investor trust and confidence. This is particularly due to the application of a broader definition of investors to include other groups such as customers, employees, and the media. Thus, the report presentation should take into account potential technical knowledge difference among those investor groups.

Hence, the main purpose of this study is to investigate whether Malaysian corporations take advantage of the greater flexibility offered in presenting non-financial narrative to improve their financial communication to their stakeholders. Specifically, the objectives of this study are: (i) to ascertain whether the non-financial narrative section is presented in a more readable style than the financial narrative section, (ii) to test consistency of readability between narrative types, and (iii) to examine variability of readability across companies.

Even though the issue of annual report readability has received considerable attention among researchers in corporate communication, most studies have been carried out in western countries where their corporate communication is primarily conducted in English. Thus, this study is expected to contribute to the earlier findings on corporate communication literature, particularly for the countries where English is regarded as the second language. Apart from that, the findings would also enable cross-country comparison on annual report readability. Lastly, the study findings would also provide empirical evidence on how Malaysian companies align their strategy in communicating their financial performance towards fulfilling the needs of various groups of stakeholders. 


\section{READABILITY CONCEPT AND MEASUREMENT}

The readability concept has been characterised by various definitions. Dale and Chall (1948, p.

13) defined readability as:

\begin{abstract}
the sum total (including interactions) of all those elements within a given piece of printed material that affects the success, which a group of readers have with it. The success is the extents to which they understand it, read it at optimum speed and finds it interesting.
\end{abstract}

Their definition suggested three important qualities of readable writing, i.e. reader comprehension, fluency, and interest, to ensure a successful process of reading. Comprehension concerns the readers' ability to understand the passage, fluency refers to their ability to read the passage at the most favourable speed, while interest relates to the readers' motivation to keep on reading the passage.

From a different viewpoint, Lesikar (1968,

- p. 190) considered written material as readable when the reader is able to comprehend the intended message on the first attempt. Furthermore, the passage conveys the message to the readers without error and it takes minimum effort by the readers. This definition emphasises on the qualities of readable writing. The qualities include ease of reading, clear writing, and minimum effort require from readers. An existence of those qualities would help readers to understand the conveyed messages easily. However, he noted that poor readability does not necessarily mean that the readers do not understand the passage, but they might need extra effort to interpret the message correctly.

However, it is important to note that both definitions do not specifically mention the characteristics to differentiate between readable writing and poor writing, which later creates difficulties in measuring readability of written materials. Subsequently, a variety of techniques have been proposed to measure readability of written materials including subjective assessment, objective question and answer technique, readability formulae, table and charts, and cloze procedure (Gilliland, 1972).

Among all the possible techniques, the readability formula has emerged as the most widely used technique in measuring reading difficulties of various written materials. The readability formula popularity is due to its ability to predict whether the target audience is likely to be able to read the written passage in an objective manner (Courtis, 1998).

Notwithstanding the many factors that could affect readability of written materials such as the content of the passage, style of writing, presentation, and its organisation, most readability formulae conveniently predict readability by examining the style of writing. Specifically, the readability formulae incorporates two main indicators that are found to be a good predictor of reading difficulty, i.e. sentence length and word length (Klare, 1974).

Although sentence length and word length might not be the real cause of reading difficulty, they were found to correlate highly with sentence complexity which indirectly causes reading difficulty (Courtis, 1998). This is particularly justified as both factors affect human ability of holding a limited amount of information at one time. When too much information is presented at one time, the mind cannot grasp it in a single reading. Hence, the longer the sentence, the harder it is to understand the passage. Similarly, shorter words tend to communicate better than longer words, as long words would slow down the reading speed and make understanding more difficult. This is no exception even when readers understand the long words (Lesikar, 1968).

Some of the readability formulae which have been mostly cited are Flesch Readability Formula, Dale and Chall, Gunning Fog Index, and McLaughlin SMOG Grading (Klare, 1985). Few studies had attempted to verify the consistency of those formulae in predicting the readability of written materials (Lewis, Parker, Pound, \& Sutcliffe, 1986; Smith \& Smith, 1971; Courtis, 1986). Their findings ascertained that most formulae give consistent prediction on level of reading difficulty of the given written material. 
Prior research had also tried to find possible correlations between reading ease and reader comprehension. For example, Soper and Dolphin (1964) compared independent judges and Flesch readability formule in evaluating the readability of five written passages. The test found that both judges and readability formule have consistent rating of readability on four out of five passages. The study provided evidence that the readability formula could potentially be a good predictor of reading difficulty of written material.

Despite the simplicity, practicality, and popularity of the readability formula, its limitations had been thoroughly discussed (Irwin \& Davis, 1980; McConnell, 1982; Dreyer, 1984). For example, the readability formula does not match the reading difficulty with conceptual background of the readers. Further more, it does not consider the writer's approach to introduce new concepts in the writing and how motivational is the written material to the readers. In addition, the readability formula fails to discriminate the readability of ordered text and scrambled text. Finally, the formula does not incorporate graphic design and formatting as part of readability indicators.

- Despite its limitations, the readability formula can be a useful tool to predict readability

as long as the researchers take into accounts all those limitations in its application (Jones, 1994). Therefore, researchers should take serious precaution in interpreting their findings when applying the readability formula to measure eadability.

\section{-}

\section{Readability of Annual Reports}

Studies on the readability of annual reports had been carried out in many countries including New Zealand (Healy, 1977), United States, United Kingdom, Canada, Hong Kong ${ }^{1}$, as well as Malaysia. The major trends of most studies was either to measure readability of complete annual reports (Pashalian \& Crissey, 1952 and Soper \& Dolphin, 1964) or a specific section within annual reports. The chairman's statements/president's letters, notes to the accounts, management discussion and analysis, and audit report have all been the interest of many researchers ${ }^{2}$. Alternatively, some studies have started to compare readability across annual report sections. For example, Courtis (1986, 1995) compared the readability of president's letter and footnotes, while Schroeder and Gibson (1990) assessed the readability of management discussion and analysis section with president's letter and footnotes.

Overall, most of prior studies consistently found that the readability of corporate annual reports was either difficult or very difficult to read. This lead to the perception that the annual report is readable to a limited group of the population, since it requires higher education levels to understand. Furthermore, the studies also remarked a declining pattern of readability of annual reports over a period of time (Jones, 1988b; Azhar, 1993; Courtis, 1995).

Even though a number of readability formulae have been adopted as a measurement tool in previous studies of corporate report readability, the Flesch readability formula has become the most popular choice among researchers ${ }^{3}$. Some of the justifications for employing the Flesch readability formula are its reliability, validity, simplicity, and comparability with other research. Furthermore, several studies have noted that most formulae give consistent prediction on readability of a given reading material (Smith \& Smith, 1971; Courtis, 1986; 1987; 1995; Lewis et al., 1986).

There have been number of studies applying readability formulae to compare the readability of chairman's statement and notes to the account. One of the more relevant studies was carried out by Courtis (1986). The study examined the readability of 140 annual reports of Canadian companies for two consecutive years, i.e. 1982 and 1983. The study employed dual readability formulae, i.e. Flesch and Gunning Fog Index to compare the readability of chairman's address and footnotes section. Even though the study concluded that readability of both sections were between difficult and very difficult, a t-test result did not accumulate sufficient evidence on the existence of significant readability differences between both sections. The study also discovered that both readability formulae provide consistent prediction of readability of those annual report sections. 
Courtis then conducted a similar study in 1995 to investigate Hong Kong companies' annual reports. The study applied three readability formulae, i.e. Flesch, Fog, and Lix to both chairman's statements and footnotes section from 1986 to 1991 . The findings showed a declining pattern in readability of annual reports over time. However, the chairman's statement has a slightly greater readability score than the footnotes despite the fact that both sections were rated as difficult to read sections by all readability formulae. On top of that, industrial sectors had not given significant change on readability of both sections. Lastly, a comparative analysis reported that the readability - of Hong Kong's annual reports is consistent with other countries.

Another review on readability of chairman's statement was conducted by Schroeder and Gibson (1990). However, the study was motivated by the belief that the chairman's statement should be - presented in more readable style than notes to the accounts due to the flexibility in its presentation format and the content being least technical in nature. To prove their hypotheses, the study compared readability of management discussion and analysis (MD \& A), footnotes, and president's letter sections. They anticipated no difference - between the readability of MD \& A and president's letter since both sections generally use minimal accounting jargon, but they expected significant differences in the readability of MD \& A and footnotes. The study adopted four readability measures, i.e. sentence length, word length, Flesch Reading Ease Index, and the use of passive voice sentence. However, a test result on readability of - 40 US-based companies' annual reports proved contradicting findings. The MD \& A section was not found to be more readable than footnotes, while the president's letter was rated as more readable than MD \& A.

Chairman's statement section has also been given the same focus by Courtis and Salleh (2002) where, they investigated annual report readability of Hong Kong companies and Malaysian companies. An interesting part of this study was that, it investigated the readability of bilingual reports for each country. The study employed Flesch formula and Yang formula for Hong Kong, and Flesch formula and Yunus formula for Malaysia in predicting the readability of chairman's statements of both languages. The study concluded that the native language versions for both countries were found to be more readable than their English-written counterparts. Additionally, the English version of chairman's statements for Malaysian companies was more readable than Hong Kong.

Another local study by Azhar (1993) investigated the readability of chairman's statements of one Malaysian company over a period of 28 years. The results highlighted that the chairman's statements is considered as difficult to read and it showed a declining pattern (as indicated by Flesch Readability Index) over time.

Azhar (1993) conducted time series investigation of one company corporate report readability while Courtis and Salleh (2002) concentrated on finding evidence of bilingual corporate report readability between two countries. Both studies concentrated on the readability of the chairman's statement section. Realising the importance of the chairman's statement as a means of corporate communication, this present study has attempted to verify Malaysian companies' initiative to present this section in a more readable writing.

\section{HYPOTHESES DEVELOPMENT}

This section sets out the hypotheses tested in the present study, together with a rationale underlying each hypothesis. Based on prior literature, three hypotheses were developed. Firstly, minimal regulatory influence offers greater flexibility to the management in presenting the non-financial narrative in a more readable style than the financial narrative report (Schroeder \& Gibson, 1990). This is consistent with Courtis (1987) who contended that financial narratives, such as audit reports and footnotes would tend to have poor readability than non-financial narratives, since the corporations are more likely to report their financial result using more technical terms than non-financial narrative.

However, earlier studies showed mixed findings on this hypothesis. Courtis (1986) examined 138 annual reports of Canadian 
companies and found that the readability of chairman's statements was not statistically different from notes to the accounts. Similarly, Schroeder and Gibson (1990) also noted that nonfinancial narrative section (MD \& A) is not more readable than footnotes, despite their anticipation that the MD \& A section is less technical in nature than footnotes. On the contrary, Courtis (1995) had concentrated on Hong Kong companies' annual report and noticed that the chairman's statements have slightly higher readability scores than notes to the accounts. Thus, it could be conceivable that:

H1: There is no significant difference between - the readability of chairman's statements and readability of notes to the accounts.

Secondly, this study proposed the following yypothesis based on the expectation that the management applies consistent writing style in presenting both narratives. Thus, it is anticipated that a company with readable chairman's statements also has readable notes to the accounts, and vice versa. As reported by Schroeder and Gibson (1990), there is strong evidence to support the next hypothesis, which is as follows:

H2: There is no significant correlation between - the readability of chairman's statement and the readability of notes to the accounts.

Finally, financial narrative presentation highly regulated by applicable accounting tandards which are to ensure consistent reporting practice among companies. Thus, it is anticipated - that companies might have a tendency to use a boilerplate in presenting notes to the ceounts disclosure (Schroeder \& Gibson, 1990). furthermore, notes to the accounts section might contain more or less similar technical terminologies or jargons. Therefore, the readability of notes to the accounts is unlikely to have greater variation among companies. Conversely, the flexibility in preparing chairman's statements promotes the management to use a different level of creativity in their writing. Consequently, the readability of the chairman's statement is expected to have greater variability than notes to the accounts. It can thus be suggested that:
H3: The readability of chairman's statement among companies does not vary significantly relative to the notes to the accounts.

\section{RESEARCH DESIGN}

This study examined annual reports of the top 100 Malaysian Index linked counter (Composite Index) as of 12 June 2000. The selection of companies for Index linked counter takes into account among other factors, trading value and market capitalisation. In addition, those companies also prepared their annual reports for a wider targeted audience. Thus, bigger corporations are expected to provide more comprehensive reporting than smaller companies (Courtis \& Salleh, 2002). This approach is consistent with some earlier studies that concentrate on big corporations ${ }^{4}$.

This study had chosen the chairman's statement to represent the non-financial narrative section while notes to the accounts represent the financial narrative section. We consider the selection of chairman's statements as appropriate for at least three reasons. Firstly, investors perceive the chairman's statements a useful source of information for decision making purposes (Rogers \& Grant, 1997; Anderson, 1998). Secondly, it is the most widely read section of annual reports (Jones, 1988a). Thirdly, the chairman's statement is one of the potential means of communicating a firm's achievement and future projection (Kohut $\&$ Segars, 1992). On the other hand, notes to the accounts was selected to represent the financial sections, as it is the only part of the financial statement that is written in continuous text. This is appropriate with the readability formula requirement that is only applicable for continuous written text.

The authors obtained the annual reports of each company from the Kuala Lumpur Stock Exchange's website (now known as Bursa Malaysia) for further analysis. Three 100-word sample passages were selected from respective sections. To ensure the sample selections represent the complete passage, the sample passages were systematically selected from the beginning, from the middle, and from the end of each passage 
according to the Flesch readability formula guidelines (Flesch, 1960). Furthermore, the purpose of employing this sampling procedure is to minimise the variability effect within the passage (Courtis, 1998).

\section{Readability Measures}

The present study had considered five indicators to predict readability. The indicators were sentence length, word length, Flesch readability score, Flesch reading ease index and the use of passive voice.

Flesch readability formula takes into account the most important variables that could - affect the style of writing i.e. sentence length and word length. Generally, longer words and longer sentences would result in lower in the readability of a given written material, while the use of shorter sentences and shorter words would help to improve readability.

The Flesch readability score is represented by a standard formula ${ }^{5}$. It generates readability scores on a zero to 100 -point scale. Higher readability scores indicate easier passage, whereas lower scores indicate reading difficulty.
The readability score is further classified into different levels of reading ease as presented in Table 1. A higher readability index number represents a readable passage while lower readability index score indicates poor readability of a given written material.

Finally, as previously adopted in the studies of annual report readability (Schroeder \& Gibson, 1990, 1992; Subramaniam et al., 1993), the present study also included the use of passive voice as supporting indicators to predict readability. Lesikar (1968) suggested that minimal use of passive voice makes a sentence strong and lively. Hence, passages containing a higher percentage of passive voice signifies poor readability, whilst minimum use of passive voice improves readability. The use of passive voice was determined by calculating the percentage of sentence written in passive voice to the total number of sentences in the sample passages.

The grammar tool in Microsoft Word was then employed to determine the readability of each annual report. This tool is able to generate detailed statistics of readability, including number of words, sentence length, percentage of sentence

Table 1

Flesch Pattern of Reading Ease Index

Reading Ease Score

$$
90-100
$$

$80-89$

$70-79$

$60-69$

$50-59$

$30-49$

$0-29$
Style Description

Index

Very Easy

Easy

6

Fairly Easy

Standard

Fairly Difficult

Difficult

Very Difficult 
in passive voice, and Flesch readability score of the selected passage. Application of a computer program to compute readability measures had been introduced in earlier studies (Clatworthy \& Jones, 2001; Subramaniam et al., 1993; Smith \& Richardson, 1999).

\section{RESULTS AND DISCUSSIONS}

Table 2 shows the distribution of Malaysian index-linked companies by industrial sectors. Trading/services, industrial product, and finance represented about $60 \%$ of total companies. Meanwhile, there was about 5\% representation from hotel, infrastructure, technology, and mining sectors. One of the companies was excluded from analysis due to incomplete documentation thus valid data for analysis was reduced to 99 companies' annual reports.

Comparison of reading ease pattern between narrative types is shown in Table 3 . The result clearly showed that the Flesch readability index ranked about $70 \%$ of the companies' chairman's statements as well as notes to the accounts as very difficult to read while the remaining $30 \%$ as

Table 2

Distribution of Companies by Sectors

\begin{tabular}{lll} 
Industrial Sector & $\mathrm{n}$ & $\%$ \\
Trading/Services & 27 & 27.3 \\
Industrial Product & 16 & 16.2 \\
Finance & 14 & 14.1 \\
Properties & 13 & 13.1 \\
Consumer Product & 10 & 10.1 \\
Plantation & 7 & 7.0 \\
Construction & 6 & 6.1 \\
Hotel & 2 & 2.0 \\
Tnfrastructure & 2 & 2.0 \\
Technology & 1 & 1.0 \\
\hline
\end{tabular}

Table 3

Flesch Reading Ease Pattern by Narrative Types

\begin{tabular}{lcccc}
\hline Style Description & \multicolumn{2}{c}{ Chairman statements } & \multicolumn{2}{c}{ Notes to the Account } \\
\cline { 2 - 5 } & $\mathrm{n}$ & $\%$ & $\mathrm{n}$ & $\%$ \\
\hline Difficult & 26 & 26.3 & 22 & 22.2 \\
Very Difficult & 73 & 73.7 & 77 & 77.8 \\
Total & 99 & 100 & 99 & 100 \\
\hline
\end{tabular}


difficult to read. This finding is consistent with what have been concluded in earlier studies (Soper \& Dolphin, 1964; Smith \& Smith 1971; Barnett $\&$ Leoffler, 1979; Courtis, 1987). Thus, we may expect that the passages would require higher level of education or knowledge for it to be able to be understood easily.

Table 4 presents descriptive statistical information by readability indicators. The result showed relatively similar means for all readability indicators between narrative types, except for the use of passive voice. It was noted that chairman's statements used far less passive voice sentences (about 18\%) as compared to notes to the accounts (49\%). The average Flesch readability score for both narratives types was about 25 , which was considered as very difficult to read. It was also anticipated that both narratives types would have similar variability among companies as indicated by the standard deviation.

Table 4

Comparative Descriptive Result by Narrative Types

Readability indicators

\begin{tabular}{|c|c|c|c|c|}
\hline $\begin{array}{l}\text { Sentence } \\
\text { Length }\end{array}$ & Word Length & $\begin{array}{l}\text { Flesch } \\
\text { Score }\end{array}$ & $\begin{array}{l}\text { Flesch } \\
\text { Index }\end{array}$ & $\begin{array}{c}\% \text { of Passive } \\
\text { Voice }\end{array}$ \\
\hline
\end{tabular}

Average

$\begin{array}{llllll}\text { Chairman's statements } & 26.4 & 183 & 24.89 & 6.74 & 17.7 \\ \text { Notes to the accounts } & 26.1 & 184 & 24.53 & 6.78 & 49.2\end{array}$

Minimum / Maximum

Chairman's statements

$17.8 / 48.0$

$164.8 / 202.2$

$5.2 / 44.5$

$6 / 7$

$0 \% / 55 \%$

Notes to the accounts

$17.7 / 53.8$

$159.9 / 203.9$

$1.3 / 36.5$

$6 / 7$

$0 \% / 90 \%$

- Standard Deviation

Chairman's statements

5.1

7.9

8.1

0.4

13.9

Notes to the accounts

5.6

6.5

6.1

0.4

17.6

\section{Comparative Readability between}

\section{Narrative Types}

Earlier studies on comparative readability have employed either parametric or non-parametric tests. The use of parametric tests was mainly due to the constraint with their small samples. Furthermore, Lewis et al. (1986) highlighted that the use of parametric tests might not be considered appropriate as the readability score is not a real ratio data. With that argument, this study employed non-parametric test statistics, i.e. the Sign test as to compare the readability estimate between the two sections. Moreover, the use of Sign test enables comparison of the findings with an earlier study by Schroeder and Gibson (1990) $)^{6}$.
The non-parametric test results obtained are presented in Table 5. It clearly showed that significant difference at the 0.05 significant level was only apparent in sentence length $(\mathrm{p}=0.04)$ and percentage of passive voice sentence $(\mathrm{p}=$ 0.00 ). There were 38 out of 99 companies that present their chairman's statement using shorter sentences, while 88 companies successfully present their chairman's statement in less passive voices sentence than the financial narrative section. Thus, we may expect that companies tend to minimise the use of passive voice sentences when they are not restricted by regulatory requirements. However, no significant difference was found between the narratives in terms of word length $(\mathrm{p}=.31)$, Flesch readability score 
$(\mathrm{p}=.84)$ as well as Flesch reading ease index ( $\mathrm{p}$ $=.64$ ). Based on the Flesch index indicator, only 18 out of 99 companies present their chairman's statements in more readable writing than notes to the accounts, while another 59 companies have equal readability index on both narratives.

Therefore, the study could not accumulate sufficient evidence to reject hypothesis 1 . Overall, these results implied that the management fails to fully take the opportunity to improve their corporate communication by presenting their chairman's statements in a more readable style, despite having greater flexibility on its presentation, except for the use of minimal passive voice.

The findings of the current study are consistent with those of earlier studies by Courtis (1986), and Schroeder and Gibson (1990), which were also unable to provide sufficient evidence of potential differences on readability between narrative types despite greater flexibility available in writing the narrative sections.

Table 5

Comparative Readability between Narratives

\begin{tabular}{lccccc}
\hline & \multicolumn{5}{c}{ Readability Indicators } \\
\cline { 2 - 7 } & Sentence & Word & Flesch & Flesch & $\%$ of Passive \\
Length & Length & Score & Index & Voice \\
\hline
\end{tabular}

Sign Test

Notes is more readable than Chairman

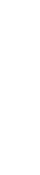
statements
Chairman's statement is more readable than Notes

Equal score between both narratives (ties)

\begin{tabular}{|c|c|c|c|c|}
\hline 59 & 44 & 51 & 22 & 9 \\
\hline 38 & 55 & 48 & 18 & 88 \\
\hline 2 & 0 & 0 & 59 & 2 \\
\hline 99 & 99 & 99 & 99 & 99 \\
\hline $.04 *$ & .31 & .84 & .64 & $.00 *$ \\
\hline
\end{tabular}

Sign Test significant at the 0.05 level (2-tailed)

Readability Consistency between Sections

- As for second hypothesis, the study tried to find evidence whether the readability of chairman's sfatement is consistent with readability of notes to the accounts with an expectation that the management applies a consistent writing style on both narratives. This research employed a nonparametric correlation test, i.e. the Spearman rank correlation test, to confirm the hypothesis. The correlation test result summary in Table 6 provided no statistical evidence at the $p=0.05$ level to infer that readability of the chairman's statement has significant correlation with the readability of notes to the accounts in terms of sentence length, Flesch score, Flesch index, and the use of passive voice. However, there was a significantly negative correlation between sentence length of both sections $(p=0.005)$. This result implied that a company which has shorter word length in presenting the chairman's statement has a tendency to have longer word length on notes to the accounts and vice versa.

Hence, looking from overall result perspective, the study provides insufficient evidence to infer that writing style of the management is consistent for both sections as only one of readability indicators showed significant correlation. Hence, we could not conclude that 
company with high readability of chairman's statement also has high readability of notes to the accounts. Likewise, poor readability of the chairman's statements does not always resulted in poor readability of notes to the accounts.

However, the findings of the present study do not support the previous research by Schroeder and Gibson (1990) which found significant correlation on all readability measures except for the use of passive voice. This might due to earlier study compared readability of MD \& A with notes to the accounts. There was no specific analysis took place to compare readability between president's letters with notes to the accounts. Other than that, cultural difference factor is potentially influence the finding (Subramaniam, 1993). In this case, Schroeder and Gibson (1990) conducted the study in English spoken country while present study investigates readability on non-English speaking country.

Table 6

Readability Consistency between Narratives

Notes to the accounts

\begin{tabular}{|c|c|c|c|c|c|c|}
\hline & & $\begin{array}{l}\text { Sentence } \\
\text { Length }\end{array}$ & $\begin{array}{l}\text { Word } \\
\text { Length }\end{array}$ & $\begin{array}{l}\text { Flesch } \\
\text { Score }\end{array}$ & $\begin{array}{c}\text { Flesch } \\
\text { Index }\end{array}$ & $\begin{array}{c}\% \text { of passive } \\
\text { Voice }\end{array}$ \\
\hline \multirow{5}{*}{ 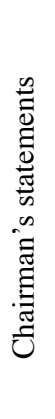 } & Sentence Length & $\begin{array}{l}-.015 \\
.879\end{array}$ & & & & \\
\hline & Word Length & & $\begin{array}{l}-.280 \\
.005^{*}\end{array}$ & & & \\
\hline & Flesch Score & & & $\begin{array}{l}-.120 \\
.236\end{array}$ & & \\
\hline & Flesch Index & & & & $\begin{array}{c}-.098 \\
.334\end{array}$ & \\
\hline & $\%$ of passive Voice & & & & & $\begin{array}{l}-.076 \\
.454\end{array}$ \\
\hline
\end{tabular}

* Spearman Rank Correlation test significant at 0.05 level (2-tailed)

Variability of Readability among Companies

The last hypothesis tried to determine whether the readability of chairman's statement has greater dispersion between companies than notes to the accounts. We employed coefficient of variation $(\mathrm{COV})$ as a measurement of dispersion/ variability as previously employed in earlier studies (Courtis, 1998; Clartworthy \& Jones, 2001). COV is more useful than standard deviation in measuring variability as it can remove the size effect between the two data series
(Courtis, 1998). Thus, it does avoid misleading interpretation of the result. COV is a product of dividing standard deviation with sample mean. Higher COV indicates that data dispersion is more variable while lower COV indicates lower variability of data dispersion.

Table 7 presents the result of variability estimates for both sections. The result showed that readability score of the chairman's statements was more variable than notes to the accounts with the COV of $32.5 \%$ and $24.9 \%$ respectively. Similarly, the result indicated greater variability 
on the use of passive voice between both sections with which chairman's statements (78\%) showed greater variability among companies than notes to the accounts $(36 \%)$.

Table 7

Readability Consistency among Companies

\begin{tabular}{llllllll}
\hline \multirow{2}{*}{ Readability Indicators } & \multicolumn{3}{c}{ Chairman statements } & \multicolumn{3}{c}{ notes to the accounts } \\
\cline { 2 - 7 } & mean & s.d.* & c.o.v.** & mean & s.d. & c.o.v. \\
\hline Sentence Length & 26.4 & 5.1 & $19.3 \%$ & 26.1 & 5.6 & $21.4 \%$ \\
Word Length & 183.8 & 8.2 & $4.5 \%$ & 184.1 & 6.6 & $3.6 \%$ \\
Flesch Readability Index & 6.74 & 0.4 & $5.9 \%$ & 6.78 & 0.4 & $5.9 \%$ \\
Flesch Readability Score & 24.9 & 8.1 & $32.5 \%$ & 24.5 & 6.1 & $24.9 \%$ \\
\% of passive sentence & 17.7 & 13.9 & $78.5 \%$ & 49.2 & 17.6 & $35.8 \%$ \\
\hline
\end{tabular}

* Standard deviation

Coefficient of variation

This result indicates that companies have eater inconsistencies in the use of passive voice in the chairman's statements than Notes to the aceounts. This finding confirms the prediction that companies have greater flexibility in presenting their chairman's statements than Notes to the accounts. Hence, Hypothesis 3 is rejected as the hairman's statements have greater variation in ts readability score between companies. This is consistent with the assumption that the companies apply different creativity in presenting the chairman's statements, but tend to use 'boilerplate' disclosing notes to the accounts.

However, these findings are not comparable ith previous studies as there were no attempts to examine directly the possible variability of readability across companies.

\section{CONCLUSIONS AND LIMITATIONS}

The purpose of present study was to determine companies' initiative to improve corporate communication by presenting a non-financial narrative report in a more readable style than financial narrative report. However, the major findings of this study found no significant differences between the readability of both the chairman's statements and notes to the accounts for all readability indicators except for the use of passive voice. Thus, overall findings provided no support to the hypothesis that the chairman's statements could be written in a more readable writing style, even though there was no requirement to comply with the strict accounting regulations. However, it was found that the management presented the chairman's statements in a substantially less passive voice than notes to the accounts.

Further statistical analysis reveals no significant correlation exists between the readability of firm's chairman's statements and notes to the accounts. Obviously, it seems that firms with highly readable chairman's statements are unlikely to have highly readable notes to the accounts. Similarly, firms with poor readability in presenting the chairman's statements do not necessarily indicate poor readability for their 
notes to the accounts. In short, companies are noticeably inconsistent in their writing styles for both narrative types.

Lastly, analysis of variability indicates that readability of the chairman's statements has greater variability among companies than notes to the accounts. It was found that, greater flexibility in presenting chairman's statements motivates companies to employ different writing style, whilst strict regulatory requirements influence the companies to use standard approach in preparing their notes to the accounts.

The evidence from this study suggests that public companies in Malaysia lose an opportunity

- to improve their reporting communication through annual reports despite wider flexibility in presenting the non-financial narrative report.

Hence, it is recommended that management to pay more attention in drafting the chairman's statements so that it is to be readable by wider groups of audience especially for average or naïve investors who hardly understand the financial section.

It is suggested that the management presents the chairman's statement section in a clearer and a more concise manner for the reader's ease of understanding. In such case, the yse of plain English in its preparation is highly recommended. Management should also be aware that short sentences always communicate better than long sentences, and short words are generally more understandable than long words. Finally, yet most importantly, the management may employ a simple and cost-effective readability prediction tool, such as a readability formula to assess quickly the readability of their annual reports.

Several limitations of our study should be pointed out. Firstly, the study was not specifically designed to measure readability of annual reports prepared in other languages. Hence, poor readability of English narratives is not an indicative of poor readability of nonEnglish narratives. Secondly, the present study has examined top 100 companies' annual reports, which represents only the most active stocks in the country. As such, it requires careful consideration in interpreting the result to the listed companies as a whole.
Finally, it is recommended that further research be undertaken in the following areas: (i) to compare readability of top 100 companies with bottom 100 companies based on other criteria, (such as market capitalisation, turnover, net profit, etc.), (ii) comparative readability across industrial sectors, and (iii) comparative studies of annual reports readability between Asian countries.

\section{END NOTES}

1 Some of the readability studies by country: New Zealand (Healy, 1972), United States (Worthington, 1979; Schroeder \& Gibson, 1990, 1992; Subramaniam et al., 1993), United Kingdom (Jones, 1988b; Smith \& Taffler, 1992a, 1992b; Canada (Courtis, 1987), Hong Kong (Courtis, 1995, Courtis, 1998; Courtis \& Salleh, 2002;Courtis, 2004) and Malaysia (Azhar, 1993; Courtis \& Salleh, 2002).

2 Examples: Chairman's statements/President's Letter (Soper \& Dolphin, 1964; Courtis, 1987; Jones, 1988b; Subramanian et al., 1993; Courtis, 1998; Courtis \& Salleh, 2002), audit report (Barnett, 1979) and notes to the accounts/Footnotes (Smith \& Smith, 1971; Worthington, 1979 and Healy, 1977).

3 Some of the studies which employed Flesch Readability formula: Pashalian \& Crissey, 1952; Soper \& Dolphin, 1964; Smith \& Smith, 1971; Healy, 1977; Courtis, 1986; jones, 1988; Schroeder \& Gibson, 1990; Subramaniam et al., 1993; Courtis, 1998; Courtis and Salleh, 2002).

4 see for exampes: Courtis \& Hassan, 2002; Pashalian \& Crissey, 1952; Schroeder \& Gibson, 1990; Smith \& Smith; 1971 and Worthington, 1979.

5 Flesch Readability Score $=206.835-1.015 S L$

- 0.846WL, where SL represents Average Sentences Lenghth (Number of words/number of sentences) while WL represent Word Length (Number of syllables/100 words).

6 Authors also attempted to excute other statistical analysis i.e. Paired t-test and Wilcoxon Signed rank Test. However, those test provided consistent findings as that was employed fot this report. 


\section{REFERENCES}

Anderson, R. H. (1998). Regulating corporate annual reports in Australia. Business and Economic History, 27(2), 522 - 34.

Azhar, A.R. (1993). Kajian membujur tentang kebolehbacaan penyata/ulasan pengerusi dalam laporan korporat sebuah syarikat di Malaysia (trans: A longitudinal study on the readability of the chairman's statements in corporate report of a company in Malaysia), Kedah: Jawatankuasa Penerbitan Universiti Utara Malaysia (UUM).

arnett, A. \& Leoffler, K. (1979). Readability of accounting and auditing messages. The Journal of Business Communication. 16(3), $49-59$.

.

Chiu, P. (1996). Trusting the figures: Investors want more information. Australian Accountant, 66(7), 44 - 46.

Clatworthy, M. \& Jones, J. M. (2001). The effect of thematic structure on the variability of annual reports readability. Accounting, Auditing \& Accountability Journal, 14(3), 311- 326.

Courtis ((1986). An investigation into annual reports readability and corporate risk -return relationship. Accounting and Business Research, (Autumn), 285 - 294.

Courtis, J. K. (1987). Fry, Smog, Lig and Rix: Insinuations about corporate business communication. The Journal of Business Communication, 24(2), 19 - 27.

Courtis, J. K. (1995). Readability of annual reports: Western versus Asian evidence. Accounting, Auditing and Accountability Journal, 8(2), 4-17.

Courtis, J. K. (1998). Annual report readability variability: Test of the obfuscation hypothesis. Accounting, Auditing and Accountability Journal, 11(4), 459 - 72.
Courtis, J. K. \& Salleh, H. (2002). Reading ease of bilingual annual reports. The Journal of Business Communication, 39(3), 394 -414 .

Courtis, J. K. (2004). Corporate report obfuscation: artefact or phenomenon? The British Accounting Review, 36, 291-312

Dale, E. \& Chall, J.S. (1948). A formula for predicting readability. Educational Research Bulletin, 27, 11-20 and 37-54.

Dreyer, L. G. (1984). Readability and responsibility. Journal of Reading. (January), $334-338$.

Flesch, R. F. (1960). How to write, speak, and think effectively. New York: Harper and Row.

Gilliland, J., (1972), Readability. London: University of London Press.

Healy, P. (1977). Can you understand the footnotes to financial statements? Accountant's Journal, 56, 219-22.

Irwin, J.W. \& Davis, C.A. (1980). Assessing readability: The checklist approach. Journal of Reading, (November), 124 -130 .

Jones, M. J. (1988a). Annual corporate reports: A waste of time and money? Management Accounting, 66(2), 40 - 41.

Jones, M. J. (1988b). A longitudinal study of the readability of the chairman's narratives in the corporate reports of a UK Company. Accounting and Business Research, 18(72), 297-305.

Jones, M. (1994). Readability of accounting narratives. Management Accounting. 72(4), 28.

Klare, G. R. (1974/1975). Assessing readability. Reading Research Quarterly, 10(1), 63 -102 . 
Klare, G. R. (1985). How to write readable English. London: Hutchinson \& Co Ltd.

Kohut, G. F., \& Segars, A. H. (1992). The president's letter to stockholders: An examination of corporate communication strategy. The Journal of Business Communication. 29(1): 7 -

Lesikar, R. V. (1968). Report writing for business (Revised edition), Illinois: Irwin.

Lewis, N. R.; Parker, L. D.; Pound, G. D. \& Sutcliffe, P. (1986). Accounting report readability: The use of readability techniques. Accounting and Business Research, (Summer): $199-213$.

McConnell, C. R. (1982). Readability formula as applied to college economics textbooks. Journal of Reading, (October), 14 - 17.

Pashalian, S. \& Crissy, W, J. (1952). Corporate annual reports are difficult, dull reading, human interest value low, survey shows. Journal of Accountancy, (August): 215 $-219$.

Rezaee, Z., \& Porter, G. L. (1993). Can the annual report be improved? Review of Business, $15(1), 38-41$.

Rogers, K. R. \& Grant, J. (1997). Content analysis of information cited in reports of sell-side financial analysts. Journal of Financial Statement Analysis, 3(1), p. 17 - 30.

Schroeder, N. \& Gibson, C. (1990). Readability of management's discussion and analysis. Accounting Horizon, 4 (4), 78 - 87.
Schroeder, N. \& Gibson, C. (1992). Are summary annual reports successful? Accounting Horizon, 6 (2), 28 - 37.

Smith, D. \& Richardson, G. (1999). The readability of Australia's taxation laws and supplementary materials: An empirical investigation. Fiscal Studies, 20(3), p. $321-49$.

Smith, J. E. \& Smith, N. P. (1971). Readability: A measure of the performance of the communication function of financial reporting. The Accounting review, July, $552-561$

Smith, M. \& Taffler, R. (1992a). Readability and understandability: Different measures of the textual complexity of accounting narrative. Accounting, Auditing and Accountability Journal, 5(4), 85 - 98.

Smith, M. \& Taffler, R. (1992b). Chairman's statements and corporate financial performance. Accounting and Finance, 32(2), $75-90$.

Soper, F. J. \& Dolphin, R. J. (1964). Readability and corporate annual reports. The Accounting Review, (April): 358 - 362.

Subramaniam, R., Insley, R.G., \& Blackwell, R. D. (1993). Performance and readability: A comparison of annual reports. The Journal of Business Communication, 30 (1), 49 - 61.

Worthington, J. S. (1979). More understanding with simpler footnotes: One footnote is not worth a thousand words. CA Magazine, $112,44-47$. 